\title{
Growing Acts of Indiscipline in Ghanaian Schools: Perception of Students and Teachers at Abuakwa South Municipality
}

\author{
Kennedy Nyeseh Ofori \\ Department of Education Studies \\ Wesley College of Education, Kumasi, Ghana
}

\begin{abstract}
Indiscipline in schools has attracted the attention of many people and has eventually become the focus of discussions on many platforms. The purpose of the study was to find out the perceptions of teachers and students at the Abuakwa South Municipality of Ghana on student indiscipline behaviours. The study employed the descriptive survey and the approach was concurrent mixed method, involving bothquantitative and qualitative paradigms. Purposive and simple random sampling methods were used to obtaina sample size of five hundred and thirty (530) respondents. The main instruments used for the study were questionnaire and a semi-structured interview guide. Data was analysed using inferential statistics and content analysis. Findings from the study revealed that; there was no perceptual difference between students and teachers views on acts that constitute disciplinary behaviours. Additional, there were differences in thestudents and teachers perceptions of the influences of peer pressure on students' disciplinary behaviours. Itwas recommended among others that peer counselling sessions should be organized periodically among students for them to be aware of acceptable behaviours in the school system and how they can maintain desirable behaviours.
\end{abstract}

Keywords: Perception, Indiscipline, Disciplinary Behaviour, Counselling, Junior High School.

\section{Introduction}

The primary objective for establishing a school is to train the hands, heart and heads of individuals. In order words, the main aim of schools is to develop the cognitive, affective, and psychomotor skills of learners in order to become functional in the society socially, politically, and economically. According to the Ghana Headteachers' Handbook (2010), Schools are purposeful institutions set up by the society to provide instructions for the systematic education of learners. Through the School, the society hopes to inculcate good morals and gets its people to conform to the norms and values of the society. Society therefore places emphasis on the type of knowledge imparted to learners so as to achieve these goals. Education should therefore be worthwhile to the society. Afful-Broni (2004), added that the school, since it is a formal organization, has certain unique structures among other things. He again stated that a school has a set of norms, rules and regulations, which are usually very clear to its members. Hence, a formal organization such a school has to have rules and procedures, which are well spelt out, and many of which must be complied. This implies that leaders in any formal organization such as the school are quite mindful of these sets of norms or rules and try to enforce them. Students as well as teachers are in a place of formation, and must abide by the rules, else many may go astray, as Ofori, Tordzro, Asamoah \& Achia (2018) emphasized; "no student is exempted from school rules and regulations".

Indiscipline remains an old human phenomenon; its impact on our Junior High school students today could be ominous and obnoxious. This is because Junior High school education marks a serious turning point in the personality development of the student, so every effort must be made towards minimizing incidence of indiscipline among students. Indiscipline acts such as smoking, drinking alcohol, rioting, rudeness, truancy among others, tend to affect effective teaching and learning in school. Research findings indicate that student indiscipline in Senior High Schools manifested in various ways has now become a common occurrence and trickled down to the Junior High Schools. The closing of schools as a result of 
wanton students' 'demonstrations, frequent boycott of classes have rendered school administration a serious problem (Azogor, 2016). This affects the studies of the majority of students who are not responsible for problems created by others who are apparently in the minority.

Effah \& Mensah-Bonsu (2001) in a study point out that; in Ghana, indiscipline seems to be on the increase. There are acts of indiscipline going on in most of our societies; often cases of rape and armed robbery are reported in the daily newspapers. The school as a social unit deals essentially with the responsibility of providing wholesome experiences and opportunities for social intervention, self-expression and self-development as well as shaping attitudes, opinions and values of students. In the words of Adentwi (2005) and Wolfgang (1999), the noble objective of the government, parents, educationists, clergy and teachers is being hampered by indiscipline that has reared its head in our schools.

The level of indiscipline leaves much to be desired. Indiscipline in Ghanaian schools takes many forms such as truancy or rude behaviour. The increase in indiscipline has been the concern of citizens and the government. Of late, students go to the extent of stealing outside the school environment and some are also involved in armed robbery. Sexual misconduct among students is on the rise in classroom and under trees (Effah \& Mensah-Bonsu, 2001). They added that, cases of demonstrations, either peaceful or violent, happen often. The least provocation makes students boycott classes, refuse to take their meals or write letters to threaten the authorities. Some go to the extent of vandalising school property and maiming some of the staff members. In some instances, the headmaster, accountants, matrons, house parents and security men have been physically manhandled or assaulted.

Widespread of news of indiscipline in schools abound in most Ghanaian newspapers. For instance, The Daily Graphic of June 21, 2001 report of increase abuse of drugs particularly marijuana among students as reiterated by Ghana's Narcotic control board (Amankwa, 2014). In another development, the Ghanaian Times of September 2001 as cited in Adinkrah (2005) also reported that student violence these days involved the use of guns. Another significant revelation about students' indiscipline was in the Daily Graphic, Saturday, June 6, 2016 captioned "Adolescent Pregnancy on the Rise". The report had it that adolescent pregnancy is on the increase in Ghana, as one out of every seven pregnancies in the antenatal clinics in the country is adolescent related. According to the 2003 Ghana Demographic Health Survey, thirty-eight percent (38\%) of female adolescents who were sexually active became pregnant while seven percent (7\%) of them terminate their pregnancies. It is therefore worth noting that, most of the victims of these anti-social acts were committed by students. There are certainly many of such horror stories and it is hard to avoid the impression that there has been a dramatic change for the worse in the last few years, and the above reports show that, such negative acts of indiscipline in our schools these days are spreading and need special attention and interventions.

Given the fact that teachers and students are the principal actors in the school, it is only proper that their perceptions, sentiments and understanding on students' indiscipline are surveyed as a necessary first step towards understanding students' disciplinary problems and provide solutions to them.

\section{Statement of the Problem}

Ngozi (2004) in a research finding noted that, indiscipline in schools particularly at the Junior and Senior High school levels is reaching an alarming proportion. Ngozi argued' that it is because High School population is largely made up of the adolescent age group who are going through a transitional period, that is from childhood to adulthood, and also because of the developmental changes that they are experiencing tend to stand against authority.

By the recent educational reform programme introduced in Ghana, one enters Junior High school by the age thirteen and may complete by the age of sixteen which falls within the adolescent age group widely accepted as thirteen to nineteen years in Ghana (Adentwi, 2005). It is generally believed that it is because of the developmental crises these students experience that they tend to misbehave in school. In spite of the incessant effort made at curbing indiscipline in Junior High schools in Ghana and also within the Abuakwa South Municipality, the problem still persists and growing at an alarming rate.

\section{Purpose of the study}

The main purpose of the study was to find out the perceptions of teachers and students on indiscipline among Junior High School students in Abuakwa South Municipality of the Eastern Region of Ghana. In this respect, the study sought to investigate whether there are conflicts in what constitutes indiscipline among 
students and teachers and also how peer groups could influence students' indiscipline behaviour. This study assumes that in order to find solutions to the problem of indiscipline behaviours among students it is necessary to examine the problem from both students' and teachers' perspectives so that attempt could be made to reconcile any differences in their perceptions of what constitute indiscipline behaviour.

\section{Research questions}

1. What behaviours do teachers and students perceive to constitute indiscipline among students in Abuakwa South Municipality of Ghana?

2. To what extent do peers influence indiscipline behaviour among students?

\section{Hypotheses}

Based on the research questions, the following null hypotheses were generated for the study:

1. There is no significant difference between the perceptions of teachers and students about what constitute indiscipline behaviours in schools in Abuakwa South Municipality.

2. There is no significant difference between perceptions of teachers and students on the influence of peer group pressure on student indiscipline.

\section{Review of Related Literature \\ School Discipline}

School discipline to Cotton (2001) is a form of discipline appropriate to the regulation of children and the maintenance of order in schools. The term refers to students complying with a code of behaviour often known as the schools rules. These rules may, for example define the expected standards of clothing, timekeeping, social behaviour and work ethic. The term discipline according to Cotton may also be applied to the punishment, that is, the consequence of transgression of the code of behaviour. For this reason, the usage of school discipline sometimes means the administration of punishment, rather than behaving within the school rules.

Kuh, Kinzie, Schuh \& Whitt, (2011) indicated that the aim of school discipline is ostensibly to create a safe and happy learning environment in the classroom and the school as a whole. Where a teacher is unable to maintain order and discipline, students may become unmotivated, indiscipline and distressed, leading to chaos and anarchy. In the words of Afful-Broni (2004) whatever is the motivation for a student's good behaviour, those in authority would do well to value the good atmosphere that a disciplined life can give birth to. He further pointed out that since a lot goes into consideration in order to label a student as disciplined or not, it would therefore be unfair on the part of a teacher to brand a student as undisciplined without due regard to what may be going on in his home. Apart from the necessary foundations of law and order, which are good grounds for a disciplined atmosphere, those in authority must also be firm in their dealing with students. This implies that students must be helped to understand that self-discipline is the fruit of firmness in obedience to rules and procedures. According to Sheldon \& Epstein (2002) school discipline has two main goals: to ensure the safety of students and also to create an environment conducive for learning. It is however true that some of the disciplinary issues are not as violent as opined by Skiba, (2000) yet many also believed that great care must be taken else non-violent problems may develop into major student crisis.

Kuh, Kinzie, Schuh \& Whitt, (2011) posit that students mostly in the adolescence age group are in the worst period in a youth life due to their overall circumstance of living. This point is further supported by Davies (2006) as he stated "Students are no longer willing to accept the complete unquestioned authority of stereotypical teaching". They constantly seek new ways of dealing with their ever-changing situations in the school environment. In this case, the students mostly engage in what the school and society consider as undisciplined behaviour. These include smoking, drug abuse, fighting, stealing, truancy, rioting, and disobedience, lateness to school, boycott of classes, alcoholism, rape and lying (Asawoe, 2004). Generally, disciplinary problems in our schools are therefore connected with breaches of school rules and regulations.

\section{Peer pressure}

Peer group may be defined as members of the same age bracket whose attitude and behaviour patterns are similar in character such as class interest, attitudes and experiences (Santrock, 2005). According to Santrock some of the attitudes and habits that can be attributed to negative peer pressure are alcoholism, drug abuse, immoral sexual activity, burglary and armed robbery. Peer group influence has been revealed as one of the 
chief agencies by which criminal culture is acquired and incubated (Benson, 2002). A common Ghanaian saying that supports this finding is "show me your friend and I will show you your character." In a similar vein, bad companionship begets bad friends. Though peer group takes on added importance such as mobilizing energy, motivating and encouraging each other for success but on the other hand juvenile gangs recruit, stimulate and teach delinquent or the undisciplined that tend to conform to the ways of their peers. This is much compatible with the proverbial saying that "birds of the same feather flock together".

Aggrey (2001) in a study found out that, out of 5,480 juvenile offenders only 18.2 per cent had committed their offences alone. The study further proved that stealing is normally a group phenomenon, as 89 per cent of offenders charged with theft were brought to court with accomplices. The implications from these revelations are that most delinquent or indiscipline children learn their delinquent acts through gang associations. Delinquent gangs provide ready anti-social channels for the energies and special personality needs of the adolescents. A peer gang can provide security, recognition, affection and new experiences when these are not provided by the family or elsewhere in society. Furthermore, parents, caregivers and school administrator who failed to provide the needed social bond, affection and love to the adolescent create favourable breeding ground for negative peer group influence that affects school discipline.

\section{Theoretical framework}

The theoretical framework underpinning this study is the socialization theory. The adherents of this theory focus on disciplinary strategies and techniques for instilling pro-social value in the child and inhibiting antisocial ones. De-Frain, one of the proponents in socialization theory posited that "punishment is needed to instill respect and obedience, and that spanking and physical coercion are necessary for teaching morals because, children are born into the world that contains pre-existing meaning, rules and expectations leveled by their parents and other representatives of the encompassing culture. By interacting with their social environment, children are assumed to acquire the norms of society that are gradually transferred onto the child (Bandura, 2009). They also share the view that to function successfully in society, children must be included in the social system of rules, values, norms and standards of conduct. They must therefore develop internal regulations of behaviour that can guide their actions not only when they are supervised and externally controlled, but also when they are on their own without surveillance and not immediately accountable to any authority. The achievement of these tasks requires systematic and conducive parenting conditions. The emphasis in this theory is that it behooves on parents and all others who are responsible for bringing up children to adopt appropriate child rearing practices so as to instill good societal morals in the young ones so that, when they grow up, they will not depart from it. This will therefore go a long way to minimize students' indiscipline.

\section{Methodology}

\section{The research design}

The study adopted a descriptive survey and the approach was a blend of quantitative and qualitative paradigms. This design was used because it involved data collection from a fraction of the population (the sample) to generalize the findings to the entire population. Additionally, this design enabled the researcher to pose follow-up questions by way of focus group discussion to get an in-depth explanation to certain ambiguous responses in answering the questionnaire for better clarification. Similarly, Fraenkel, Waller \& Hyun (2011) points out that, obtaining answers from a large group of people to a set of carefully designed and administered questionnaire lies the heart of the survey research. Therefore, one instrument was used to support the other in the process of data collection so as to make up for the shortfall inherent in each of the instruments used, to ensure collection of authentic and an in-depth database. For instance, ambiguous responses that came up when answering the questionnaire were captured in the focus group discussion for further clarification.

\section{Study Location/Area of Study.}

This study was carried out at Abuakwa South Municipality in the Eastern Region of Ghana. Abuakwa South Municipal is one of the 254 administrative Districts/Municipals/ Metropolitan in Ghana. The estimated population for the Municipality by the 2010 Ghana Population and Housing Census was 167,896, which is made up of 81,767 males and 86, 129 females. The main language spoken in the area is "Twi" followed by 
Ga-Adangme, Ewe and Guan. Christianity remains the dominant religion practiced by the inhabitants in the Municipality. However, there are few people who prefer traditional religions and migrants from the Northern part of Ghana are who identified themselves as Moslems. The municipality is predominantly occupied by peasant farmers, petty traders and government workers of various agencies and departments (GSS, 2014). It is worth noting that, the pre-occupation of the inhabitants of the study area is seasonal and during the lean season, parents are hard hit financially and they appear to become irresponsible due to deteriorating economic conditions and austerity. The area was chosen for the study based on anecdotal evidence of high rate of student indiscipline. The researcher's familiarity of the study area also influenced its choice for the study.

\section{Population}

Fraenkel, Wallen, \& Hyun (2011), assert that a population is the group to which the research findings are intended to apply to. The target population of the study comprised all teachers and students in Junior High schools (JHS) at Abuakwa South Municipal. The total population of teachers and students in JHS at the Municipality were six hundred and fifty (650) teachers and fifteen thousand two hundred $(15,200)$ respectively for the 2016/2017 academic year (Eastern Region Annual Education report, 2017).

\section{Sample Size and Sampling Strategy}

Amoani (2005) states that sampling, is the procedure whereby elements or people are chosen from a population to represent the characteristics of the population. Sample size used was five hundred and thirty (530) respondents who were mainly teachers and students, and were randomly selected from the twenty (20) Junior High schools within the municipality. The total number of teachers that took part in the study was 120 and that of students was 410 . The schools and also the individual respondents were selected from their population using randomization. The simple random sampling was preferred because it ensured that each school, teacher and student had an equal and independent chance of being chosen.

\section{Instrumentation and data collection}

The main instruments used for the study was the questionnaire, focus group interview guide and documentation. The questionnaire was constructed based on a five (5) point Likert type scale. It contained twenty-three close-ended questions to which respondents were to show their degree of response; that is, Strongly Agree (S. A), Agree (A), Not Sure (N. S), Disagree (D), and Strongly Disagree (S. D). The questions bordered on the demographic characteristics of respondents, incidence of acts of indiscipline, perceived behaviour that constituted indiscipline among students and perceived influence of peer groups on indiscipline. The interview guide was semi-structured to enable respondents express themselves freely. A focused group interview guide which contained open-ended questions was used to direct the course of the interview. The interview was conducted through Focus Group Discussion, which allowed the researchers to discover ideas, concerns, attitudes and perceptions of people in their own terms. Focus Group Discussions often stimulate people to talk and to reveal facts and opinions that may not have been revealed otherwise. It also allows the group to clarify perceptions, attitudes or beliefs in words that were probably not easy to articulate. (Gatrell 2002). For this particular study the full group was used. The researchers deemed it expedient to also select students who misbehaved in school and were brought to book since such students would have an in-depth knowledge and experience about issues pertaining to student indiscipline and their contributions and responses would be worthwhile.

\section{Validity and reliability}

The issue of validity was addressed in this research using triangulation. Triangulation involves the use of multiple sources to enhance the rigour of the research. Validity was further established by giving the questionnaire to two post graduate students at the Cape Coast with specialization in test and measurement to modify it. Reliability according to Cohen, Marion, \& Morrison (2003), means that scores from an instrument are stable and consistent, scores should nearly be the same when researchers administer the instrument multiple times at different times and also scores need to be consistent. Reliability was achieved initially in this research by pilot testing the questionnaire and interview survey. The data collection instruments were pilot tested among thirty (30) students and five (5) teachers at Osino Presbyterian JHS in Fanteakwa District of Eastern Region of Ghana which is not part of the study area but the respondents have the same 
characteristics as the respondents for the main study. The instruments were then reviewed on the basis of issues raised and noted during the exercise.

\section{Data analysis procedure}

The statistical software (STATA 15) was used to process and analyse the quantitative data while the qualitative data (that is, interview conducted) was analysed thematically using the content analysis. With the quantitative data, the results were displayed in the form of frequencies, percentages, mean and standard deviation. Chi-square analysis was used to show the significant relationship between the variables. Both were later integrated to enable the researcher to delve deeply into the perception of students and teachers on indiscipline.

\section{Results}

The results of the study are presented as follows;

Research question one: What behaviours do teachers and students perceive to constitute indiscipline among students in Abuakwa South Municipality of Ghana?

This research question sought to find out the kinds of acts teachers and students perceive to constitute indiscipline among the students. The results are shown in table 1.

Table 1: Behaviours Teachers and Students Perceive to Constitute Indiscipline

\begin{tabular}{lccc}
\hline Statement & Mean & SD & Rank \\
\hline Being disrespectful to school authorities & 3.31 & 0.89 & $2 \mathrm{nd}$ \\
Engaging examinational malpractices & 2.74 & 0.87 & 5 th \\
Damaging school properties & 3.52 & 0.9 & 1 st \\
Involving in drug or alcohol abuse & 2.64 & 0.92 & 6 th \\
Wearing dirty or unprescribed clothing to & & & \\
school & 3.21 & 0.88 & 3 rd \\
Revenge of hatred feelings & 2.54 & 0.92 & 7 th \\
Lying to teachers or fellow students & 1.98 & 0.85 & 9 th \\
Having sexual relationships & 2.33 & 0.93 & 8 th \\
Calling some other names (nicknames) & 2.86 & 0.89 & 4 th \\
Failing to do assignment/school work & 1.76 & 0.86 & 10 th \\
\hline
\end{tabular}

The data presented in Table 1, shows the most behaviours perceived by teachers and students to constitute indiscipline act in rank order are damaging school properties, being disrespectful to school authorities and wearing of dirty or unprescribed clothes to school. It was also evident that, students failing to assignment or school work, lying to teachers or fellow students and having sexual relationships were least perceived by the respondents to constitute indiscipline.

Participants in the focus group interview mentioned bullying, having sexual relationship with student girls, teenage pregnancy, disturbing in school, abusing drugs, and drinking alcohol as indiscipline behaviour. However, some respondents also claimed they were brought before the school disciplinary committee for committing minor offences such as habitual lateness to school and playing truancy, which to them did not constitute indiscipline. As one student at school M put it:

I insulted and beat a girl in JHS 2 and the case got to the notice of the school authorities and I was summoned before the disciplinary committee for indiscipline. (PPK-M)

Another respondent also at school N said:

I was lured to "Jerusalem" (name for the palm wine base) by friends where they sell palm wine near the school compound to drink; the senior prefect detected this in my walking and mood, so he 
reported me to the assistant headmaster who also referred me to the disciplinary committee. I admitted before the committee my indiscipline behaviour and pleaded to be pardoned. (CCK-N)

The responses from the focus group discussions showed most of acts constituted indiscipline behaviour. Though the deviant acts committed are not so violent, care must be taken to nib it in the bud before seemingly less violent problems to develop into major student crisis.

Research question two: To what extent do peers influence indiscipline behaviour among students?

The purpose of this research question was to determine the extents at which students' indiscipline behavior are influenced by their peers. The results are displayed on table 2.

Table 2: Perceived Influence of Peer Activities on Indiscipline

\begin{tabular}{lcc}
\hline Statement & Mean & SD \\
\hline Having too many friends can influence indiscipline among students & 3.78 & 0.87 \\
$\begin{array}{l}\text { Students can imitate behaviour of friends more } \\
\text { Friends outside school have more influence students than those in }\end{array}$ & 3.65 & 0.9 \\
his/her school. & 3.44 & 0.88 \\
$\begin{array}{l}\text { When student does something good he/she gets more praise from } \\
\text { Peers than adults }\end{array}$ & 3.82 & 0.92 \\
Adolescents tend to be influenced by colleagues than other adults. & 3.85 & 0.92 \\
\hline
\end{tabular}

Table 2; show that for all the five items, respondents' scores on the specific statement were above the cut-off point of 2.5. This shows that teachers and students perception that peer group activities have influence on indiscipline was high. It can be seen from the table that respondents agreed that adolescents tend to be influenced more by their colleagues than other adults $(M=3.85, S D=0.92)$. Again, respondents stated that students get more praises from peers than adults when they do something good $(M=3.82, S D=0.92)$. Having too many friends was next highest to be indicated by the respondents to influence indiscipline among students $(M=3.78,0.87)$.

The qualitative data gathered from respondents in the focus group gave various views indicated that peer group pressure has much influence on students' indiscipline behaviour. This is indicated by sample of their statements. A student from school $\mathrm{X}$ advanced the following:

My friends make me happy; they understand me better so I join them in whatever they do. Sometimes we drink together and go after girls for sex. You see as a member you have to do the things everybody is doing". This student further said 'as a person when you do something good sometimes your parents or teachers will not appreciate you but your fiends will shower praises on you by giving you fun. So you will always do things that please them and they will always try to influence you more. (KKK-X)

Another respondent at school $\mathrm{W}$ retorted that:

Being with my peers is lovelier. My parents don't even have time for me. You cannot even get them to discuss anything bordering you. They are always busy at work making more money to help us. I see nothing wrong when I use spend more of my time with my friends. I am able to learn better from them.' (NNN-P)

These responses from both the qualitative and quantitative data justifies why students indiscipline is perceived to be influenced by their peers. Hence, in finding solutions to curb the growing acts of indiscipline among students, the role of peer groups cannot be underrated.

\section{Hypothesis one:}

There is no significant difference between the perceptions of teachers and students about what constitute indiscipline behaviours in Abuakwa South Municipality.

To ascertain whether significant difference exists in students' and teachers' perception on what constitute indiscipline behaviours, the results are found in table 4. 
Table 4: Summary Statistics of Difference in Teachers' and Students' Perceptions of Indiscipline Behaviours among students

\begin{tabular}{lcccccc}
\hline Group & $\mathbf{N}$ & Mean & SDT & T & df & p-value \\
\hline Teachers & 120 & 4.0291 & 0.55700 & & & \\
& & & & 1.644 & 228 & 0.101 \\
Students & 410 & 3.8872 & 0.554582 & & &
\end{tabular}

Significance at $\mathrm{P}<0.05$

As shown in Table 4, the result revealed that there was no statistically significant difference between the teachers' and the students' perception of behaviours that constitute student indiscipline. $(\mathrm{t}=1.644, \mathrm{df}=228$, $\mathrm{p}=0.101$ ). Therefore, the study hypothesis that teachers would perceive those behaviours that constitute indiscipline differently from that of students is rejected and the null hypothesis that there would be no significant difference between teachers and students in what constitute indiscipline behaviour is accepted.

\section{Hypothesis two:}

There is no significant difference between perceptions of teachers and students on the influence of peer group pressure on student indiscipline.

To determine whether significant difference exists in teachers and students perception on the influence of peer group pressure on students' indiscipline, the results are presented in table 5.

Table 5: Summary Statistics of Difference in Teachers' and Students' perception on the Influence
\begin{tabular}{lccccccc}
\multicolumn{7}{c}{ Peer Pressure on Students Indiscipline } \\
\hline Group & N & Mean & SDT & T & df & p-value \\
\hline Teachers & 120 & 3.3491 & 0.57248 & & & \\
Students & 410 & 3.1038 & 0.48884 & & & 0.001
\end{tabular}

Significance at $\mathrm{P}<0.05$

The result from Table 5; showed there was a statistically significant difference between the teachers and students in their perceptions of the influence of the peer group pressure has on students' indiscipline behaviours $(t=3.336, d f=228, p=0.001)$. Therefore the study hypothesis that there would be significant difference in students' and teachers' perceptions of the influence that peer group pressure has on student indiscipline behaviours is accepted, and the null hypothesis that there will be no significant difference between teachers and students perception of influence of peer group pressure on student indiscipline behaviours rejected. This result suggests that the teachers perceived peer pressure as influencing indiscipline behaviours more than that of the students.

\section{Discussions}

The present study found that there was no significant difference between teachers and students perceptions of acts that constitute student indiscipline behaviours. One possible reason for the similarities in the perceptions of teachers and students on acts that constitute student indiscipline behaviours in the study area might be due to the strong influence of the media in both print and electronics. There are now very interesting and captivating educational programmes on the numerous radio, TV and FM stations across the country sensitizing the youths on immoral acts abhorred by society with its attendant negative consequences suffered by adolescents who engage in such deviant acts. Furthermore, the immense role played by churches and other religious bodies in bringing to the fore the sudden increase in social vices could equally account for why adolescents for that matter, students, seem to be equally aware of acts that constitute deviant behaviours just as their teachers. 
The findings from the questionnaire and the focus group interview confirms the findings of Kuh, Kinzie, Schuh \& Whitt, (2011) that students in the adolescent age groups are in the worst period in their youth life due to their overall circumstances of living. This point is further supported by Ansawoe (1992) who stated that 'students are no longer willing to accept the complete unquestioned authority of stereotypical teaching'. They constantly seek ways of dealing with the ever-changing situation in the school environment. In this case, the students mostly engage in what school and society considered as indiscipline behaviour. These include; smoking drug abuse, fighting, stealing, truancy, disobedience, lateness to school, boycott of classes, rape and lying.

The findings of the study further revealed that there was significant difference between teachers and students in their perceptions of the influence peer group pressure has on student indiscipline behaviours. The teachers perceived peer group pressure as having more influence on student deviant behaviours than that perceived by the students. This supports earlier studies by Ngozi (2004) and Mumthas, Munnaivvir \& Gafoor (2014), who posited that, adolescents in peer group often revolt against all imposed proof and authority because to them, life is idealistic. Their revolt hinges on the development of morals and values. These developments are closely related to the individual environmental experiences. The adolescent is living in a real world of conflicting values where logic does not necessarily apply.

According to Ngozi, the adolescent is only searching for his or her personal belief based on experiences and expectations and in doing so he or she becomes very critical and fastidious, trying to find an in-depth explanation to the practices of the elders and most often the cherished values of the adolescent conflicts with those of teachers and parents implying that the adolescent will see the negative influence that their contemporaries are having on their behaviours as a way of getting the attention, recognition and approval of their peers. When students refused to do what teachers and parents ask them to do, they usually weigh the effects of their defiance on their standing among their peers. The misbehaviours at this point can be attributed to the value teenagers place on peer norms. Teenagers therefore see their behaviours in peer group as right and ideal, while teachers on the other hand, label such behaviours as bad and attribute them to negative peer group influence.

\section{Implications for Counselling Practice}

It behooves on School counsellors to orient and sensitize both staff and students with the aim to correct the stigma they have for other students who are seen as deviants and be better predisposed towards counselling and thereby avail themselves for guidance and counselling services provided by the counsellor. Finally, School counsellors should plan activities that would aim at informing students on the consequences of negative peer group influence.

\section{Conclusions and Recommendations}

The study revealed that students usually weigh the effects of their defiance on their standing among their peers because teenagers place value on peer norms. Teenagers therefore see their behaviours in peer group as right and ideal, while teachers on the other hand, label such behaviours as bad and attribute them to negative peer group influence. It is hoped that the findings of this study will enlighten educational administrators, policy makers and counsellors on the acceptable behaviours and recommended administrative style that can create an environment devoid of students' misbehaviours. The school authorities must also endeavour to foster harmonious living among staff and students for teaching and learning to go on effectively as this can help in minimizing student indiscipline behaviours. Again, School rules and regulations could be few, simple, fair and consistently enforced by teachers so that students would not become confused about what is expected of them in terms of good conduct. Lastly, School rules and regulations should be discussed and agreed upon by all parties (school authorities and students) so that students would not become confused about what is expected of them in terms of good conduct.

\section{Areas for Further Studies}

Further studies should be done into finding the effects of student indiscipline behaviour on the socioeconomic development of the country and also the the influences of parenting styles on indiscipline behaviour among students. 


\section{References}

[1] Adentwi, K. I. (2005) Teachers' and students' Perceptions of Classroom Indiscipline;A Study in Selected Senior Secondary School in the Cape Coast Municipality Unpublished M. Phil Thesis, University of Cape Coast.

[2] Adinkrah, M. (2005). Vigilante homicides in contemporary Ghana. Journal of Criminal Justice, 33(5), 413-427.

[3] Afful-Broni. A. (2004) Theory and Practical of Education Leadership in GhanaAccra: Type Company Ltd.

[4] Aggrey, K. (2001). Juvenile Delinquency in Sukura Basic School. (Case Study) U.E.W (Unpublished thesis).

[5] Amankwaah, D. A. (2014). An Alternative to Incarceration of Drug Users: A Comparative Study of Ghana and the United States (MA dissertation, University of Ghana). Retrived on 12/11/2017 from http://ugspace.ug.edu.gh/handle/123456789/8638

[6] Amoani, F. K. (2005). Research methods an Overview, Winneba: University of Education, Winneba.

[7] Ansawoe D.P. (2004). Dimensions of school Discipline. New York: Longman

[8] Azogor, F. E. (2016). Students Participation in Administrative Decision-Making in the Governance of Universities in South-South Nigeria.

[9] Baido, F.A. (2016, June,6). Adolescent Pregnancy on the Rise. Daily Graphic, p.4.

[10] Bandura, A. (2009). Social cognitive theory of mass communication. Media effects, Routledge: 110140.

[11] Benson, T. P. (2002). Classroom Discipline and school Psychology, London: The Macmillan Company.

[12] Cohen, L.Marion, L, \& Morrison, K (2003): Research Methods. (5 ${ }^{\text {th }}$ Ed). New York: Routledgetalmer.

[13] Cotton, K. (2001) School wide and Classroom Discipline Online Resource Accessed on June 8,2005 at *http://www.nwrel.org/scpdlsirs/ 5/cu9.html

[14] Davies, L. (2006). "Global citizenship: abstraction or framework for action?" Educational review 58(1): 5-25.

[15] Eastern Region Education Directorate (ERED), (2017). 2016 Annual Report, GhanaEducation Service: Unpublished

[16] Effah, P. \& Mensa-Bonsu (2001). Governance of Tertiary Education Institutions In Ghana: A manual. Legon-Accra: Adwinsa Publications (Gh) Ltd.

[17] Fraenkel, J. R., Wallen, N. E., \& Hyun, H. H. (2011). How to design and evaluate research in education, New York: McGraw-Hill Humanities/Social Sciences/Languages.

[18] Gattrell, A. C (2002): Geographies of Health: An Introduction. Oxford: Blackwell Publishers Ltd.

[19] Ghana Education Service (2010a), Headteachers' handbook (2nd ed.). Accra: Ministry of Education.

[20] Ghana Statistical Service (GSS), (2014). 2010 Ghana Population Census Report. Accra: Ghana Statistical Service (GSS), (2014). Ghana Demographic and Health Survey, Accra: GSSKuh, G.D., Kinzie, J., Schuh, J.H., \& Whitt, E.J. ( 2011). Student success in college: Creating conditions that matter, John Wiley \& Sons.

[21] Mumthas, N.S., Munnaivvir, J. \& Gafoor, A.K (2014). Students and Teachers Perception of Disciplinary Practices: Types, Reasons, Consequences and Alternatives. Guru Journal of Behavioral and Social Sciences, 2(4), 301-308

[22] Ngozi, O. (2004). An Introduction to Guidance and Counselling. Nigeria: Callop Publications.

[23] Ofori, K.N., Tordzro, G., Asamoah, E., \& Achiaa, E. (2018). The Effects of Indiscipline on Academic Performance of Junior High Schools in the Fanteakwa District of Ghana. Journal of Education and Practice, 9 (21), 109-117

[24] Santrock, J. W. (2005). Adolescence, $\left(10^{\text {th }}\right.$ Ed) New York: Mc Graw Hill.

[25] Sheldon, S. B. \& Epstein, J.L. (2002). "Improving student behavior and school discipline with family and community involvement." Education and urban society 35(1): 4-26.

[26] Skiba, R. J. (2000). "Zero Tolerance, Zero Evidence: An Analysis of School Disciplinary Practice. Policy Research Report." 
[27] Wolfgang, C.H. (1999). Solving Discipline Problems. London:Allyn and Bacon

\section{Author's Profile}

Kennedy Nyeseh Ofori received the B.Ed and M.Ed Degrees in Guidance and Counselling from the University of Education, Winneba and the University of Cape Coast in 2010 and 2014 respectively. He further obtained M.A and MPhil in HIV and AIDS Management at the University of Ghana, Legon also in 2016 and 2017. He currently works as a Tutor and Counsellor at Wesley College of Education, Kumasi, Ghana. 